\title{
APPLICATION OF THE CZECH LANDSCAPE RESEARCH EXPERIENCE IN THE DESERT ENVIRONMENT TO SUPPORT ARCHAEOLOGICAL STUDY
}

\begin{abstract}
KOLEJKA, J., MISÁKOVÁ, L., BRŮNA, V. (2010): Application of the Czech landscape research experience in the desert environment to support archeological study. Geografie, 115, No. 3, pp. 347-360. - The landscape mapping represents a traditional activity of Czech geographers for more than a century. Czech landscape research and mapping experience supported by remotely sensed data and GIS technique was used in the Al-Baharíya oasis (Egypt, Western Desert) to construct both the map of present landscape with natural and human-made objects, and the reconstruction natural landscape map showing the study area at the approximate time of early settlement. Such products present selected sites, today mostly covered with sandy dunes, where the possibility to find ancient dwelling sites is higher in analogy with sites of present archaeological excavation.

KEY WORDS: Al-Baharíya - Western Desert - Egypt - natural landscape map - present landscape map.
\end{abstract}

\section{Introduction}

The holistic landscape research has a long tradition in the Czech geography. The complex landscape maps were compiled in Czech lands since 1880s, long before the formal geographic landscape science was established in the early 20th century (L. S. Berg in Russia in 1915, S. Passarge in Germany in 1919) and the landscape ecology in 1930s (C. Troll in Germany in 1939). The peaks of the landscape maps development in the Czech geography can be seen in 1930s (see regional landscape schemes completed by Král 1930, Korčák 1936 and Moschelesová 1936), in the late 20th century (see typological landscape map Publisher by Demek, Quitt, Raušer 1975; Ivan et al. 1987; Kolejka 1992, 1999; Kolejka, Lipský 1999) and at the present time when the national Atlas of Landscape of Czech Republic is intended to be published soon (see Kolejka 2006, Kolejka, Lipský 2007). At the present, various maps of the natural and cultural landscapes compiled using traditional analogue, digital GIS and remote sensing techniques are available at scales from topological level (map scale up to $1: 10,000$ ), chorological level (from $1: 25,000$ to $1: 1,000,000$ ), regional level (from $1: 2,000,000$ to $1: 15,000,000)$ to the global level $(1: 30,000,000)$. The topological landscape maps, as well as landscape maps from lower chorological sublevels (up to 1:50,000) are applicable to support various kinds of research because of their ability to demonstrate the holistic character of the study territory in its structure and internal relationships between landscape construction components and territorial units. The attention is paid both to the natu- 
ral (present, potential, reconstructed historical) landscape maps and cultural (present, historical) landscape maps. The modern day archaeology belongs to the standard, e.g. topographic and some thematic map users. It relies on the correct area topography presentation. The application of complex landscape maps is rarely known in the archaeology regardless its wide power supporting the researcher's right imagination of the environment at present and ancient times. Some initial experiments were already done (Gojda 2000).

The present day archaeological research commonly uses traditional advantages of application of geoinformatics, especially the remote sensing as well (Gojda 2004, Parcak 2009). They assist not only the location of new findings and their introduction into territorial relationships but also in some cases the understanding of their relations of origin in the environment. Geoinformatics offers various tools for location, depiction, analysis and contextual study. These technologies make the careful object identification, location and documentation possible. The geoscience support for the archaeological research becomes quit common in the last decades. Paleolandscapes are studied in various regions of the Earth (desert regions of Middle East, Sahara, Australia, SW USA states, etc.) using science knowledge (see Stiebing 1989; Adelsberger, Smith 2009). Geomorphology - the knowledge about the fluvial landforms and their origin was applied in the documentation of Pleistocene settlement in southern Australia (Fairbairn, O'Connor, Marwick 2009), in Western and Eastern Sahara (Cremaschi, Di Lernia 1999; Sereno, Garcea, Jousse, Stojanowski, Saliège et al. 2008). Traditional Neolithic archaeological research is represented by the Western desert in Egypt, where the research is accompanied with the geoscientific field work (e.g. Kobusiewicz, Kabaciński, Schild, Irish, Wendorf 2004; Adelsberger, Smith 2007; Adelsberger, Kieniewicz, Smith 2008; Adelsberger, Smith 2009). The evidences of the lake existence on the bottom of the Baharíya oasis are dated between 8-7 ky BP (Svoboda 2006). It is not clear if the lake survived until the Roma era.

The basic responsibility for reliable data acquisition and understanding of relationships relies on sciences providing original knowledge. While analytic information is being produced by individual specialized geosciences, on the other hand it is not possible to avoid such procedures linking analytic knowledge into network of relationships. Right the knowledge about mutual relationships (and causality) between phenomena is very important for various applications of geoinformatics in the process of the study of the surrounding environment.

The ability to put information into relationships indicates the main advantage of geography. Geographic landscape science represents such synthetizing discipline yielding both the integrated geodata about the environment as well as the knowledge base making data integration possible. Linking landscape knowledge base with present digital image data sources and modern processing procedures leads to results able to support the success of the archaeological research. Set of examples of suitable linking the advantages and abilities of the landscape science with the high efficient digital geodata collection and processing using the geoinformatics tools shown in this paper can serve as some kind of an inspiration. 


\section{Archaeological research in Al-Baharíya oasis and contribution of topic geographic landscape experience}

The Western (Libyan) Desert, an integral part of Sahara, covers the territory to the West of the valley of the River Nile. The gently undulated sandy landscape covers a dissected tableland consisting of Cretaceous limestone above older sandstone layers immediately laying on crystalline fundament. Tectonic lines (fractures) allowed lava flows to reach the Earth surface. Their remnants are represented with isolated desert landmarks. The landscape, basically monotonous, is variegated with marked basins of oases. The Al-Baharíya oasis posses a special position among other large oases (Síwa, Faráfra, Dakhla and Kharga) of the Western Desert (Fig. 1). It is located very close to Lower Egypt and the valley of the River Nile before it enters the Delta $(360 \mathrm{~km}$ to SW from Cairo). A primitive agriculture developed here approximately $9000-8000$ years BP as probably one of the first Neolitic civilizations in the World (Castel, Tallet 2001; Bárta 2005; Svoboda 2005, 2006). In compliance with the latest hypotheses, when the neighboring savanna started to dry out about 8000 years BP locals from here moved to the Nile where later the civilization of Old Kingdom developed (Bárta 2007). After that the Al-Baharíya oasis continuously attracted attention of the rulers of ancient Egypt. Romans and later the first Christians lived here after the beginning of the first millennium. All of them left here numbers of artefacts. Especially the find of golden mummies from Greco-Roman period in Valley of the Golden Mummies attracted the attention of the World publicity in 1999. Up to this day it is not known where the original population was settled in the oasis when its bottom was covered with a lake. The knowledge about the present landscape and its historical natural landscape genetic processes can assist hypotheses formulation where to search for ancient settlements at the time, when the lake existed on the oasis bottom close to the present Bir el-Showish village. The re-constructed natural landscape map of that time could serve as non-traditional tool support in the decision making where to start new promising excavations.

The Al-Baharíya Oasis $\left(27^{\circ} 45^{\prime}-28^{\circ} 30^{\prime} \mathrm{N}, 28^{\circ} 30^{\prime}-29^{\circ} 10^{\prime} \mathrm{E}\right)$ has an approximate pear-shape ground-plan, narrower in the SW and wider in NE, $97 \mathrm{~km}$ long and up to $40 \mathrm{~km}$ wide (Fig. 2) and covers an area of about 2,250 $\mathrm{km}^{2}$ (Rasheed, Gad, Zoelitz-Moeller, Darwish, 2008). The elevation of the oasis bottom varies between $55-100 \mathrm{~m}$ a.s.l., while the outer edge is never below $200 \mathrm{~m}$ a.s.l. and reaches in some sites $310 \mathrm{~m}$ a.s.l. The basin bottom lies on Cretaceous sandstones (as seen in General Geological Map of Egypt) and is divided into a set of smaller sub-basins. The edges of the oasis consist of sub-horizontal Cretaceous limestone layers. Except the cuesta like margins and some lone hills, the tableland surface is covered with Eocene sands and sandstones. Many isolated hills repre-

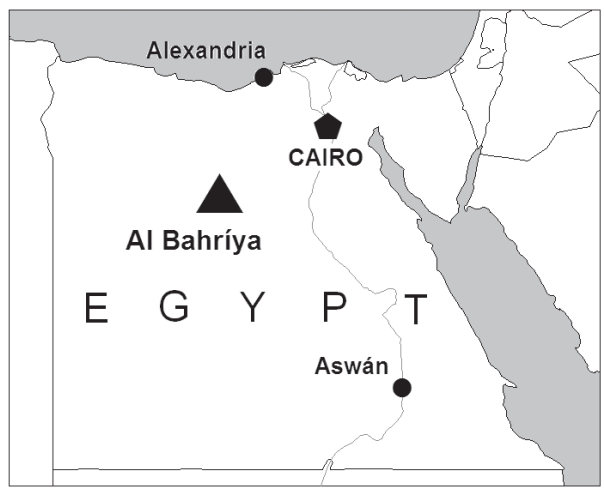

Fig. 1 - Location of the Al-Baharíya oasis 
sent examples of table mounts with tops impasted with basalt layers (Fig. 2). The weathering product layer starts with coarse limestone block on the foot of marginal oasis edge and continues down hill through coarse sands and fine sands on slope foot to clays in playas on basin bottom. The most part of this layer originated by wind transportation of Miocene and Quaternary sands. Clays in playas are transformed by the wind erosion into bizarre forms. With regard to the intense wind activity, both the erosion and accumulation land forms are subdued to changes dependently on their rock tolerance to wind. Many recent human made land forms are concentrated into the NE part of the oasis where

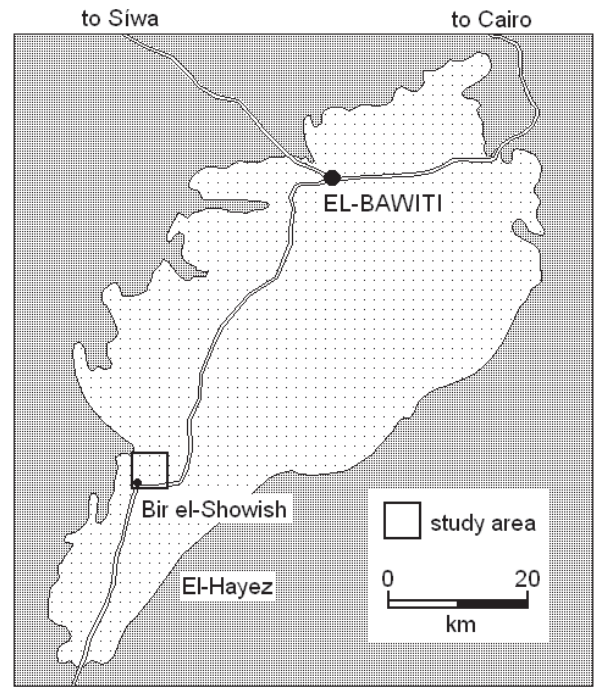

to Faráfra

Fig. 2 - Study area location in Al-Baharíya oasis the iron ore mining is still active. The ore is being transported by the railway to Helwan Steel mills near Cairo.

The construction of the present landscape map of the area of interests and the compilation of the map of reconstructed natural landscape map was possible using available knowledge about the geology, terrain, land forming processes, isolated historical data, present archaeological sites, recent satellite imagery and field research experience. The expression "natural landscape map" means the approximation of the lake coast line and the water body on one hand and the delineation of ancient drainage network important for the settlement location on the other hand in areas cultivated at the present time and on barren "sebkha" oasis bottom The other remnants of former real semiarid landscape covered under present wind blown sands were not involved into the "landscape re-construction".

Czech archeologists (Bárta, Brůna, Černý, Musil, Svoboda, Verner 2004) pay attention to the narrower and partially separated SW part of the oasis called El-Hayez, where the excavations controlled by the Czech Institute of Egyptology run at the present time. The population number in this section of the oasis is about 7,000 and locals live in seven small villages. A part of villagers travel to the „metropolis“ El-Bawiti for their jobs while the most population work in agriculture cultivating wheat, rice, table grapes, dates, olives, apricots and oranges. The present excavations run close to the northern limit of the El-Hayez oasis nearby the Bir el-Showish village. This settlement is represented by little number of houses more or less scattered in palm gardens and small fields. An extended cultivated area is in the neighborhood as well as the seasonally used land. The dry land outside the cultivated area is intersected with an ancient (probably from the Roman period - Svoboda 2005) network of the "manawars" - the underground water supply canals resistant to evaporation. The gently sloped tunnels in the depth of up to $15 \mathrm{~m}$ collect underground water and feed water wells. The tunnels were accessible by vertical pits in the distance 
every 10 meters. The detail geodetic mapping of archeological excavations and objects was completed here in the previous time (Brůna 2006). The location of the recent discovery sites into the wider landscape conditions was not done until now and the progress from this viewpoint is presented in this contribution.

\section{Available satellite imagery}

Various materials were collected to support the construction of the landscape map for the Bir el-Showish area. The data set consists of the topographic map at the scale of 1:250,000 (Sheet 4-D, Baharíya Oasis), geological map at the scale 1:2 mil., and the QuickBird satellite image taken on February 7, 2006. Because of the spatial resolution of the available maps was very low, the key role in the landscape mapping was played by the satellite image processing accompanied with detail land survey.

The QuickBird satellite images are being scanned from a sub-polar orbit at the altitude of $450 \mathrm{~km}$ from the two instruments: sensor MS (multispectral) collects data in four spectral bands (blue 0,45-0,52 $\mu \mathrm{m}$, green $0,52-0,6 \mu \mathrm{m}$, red 0,63-0,69 $\mathrm{m}$ a near IR $0,76-0,9 \mu \mathrm{m}$ ) using spatial resolution $2,4 \mathrm{~m}$, the sensor PAN (panchromatic) operates in the band $0,45-0,9 \mu \mathrm{m}$ using $0,6 \mathrm{~m}$ resolution. The real width of the scanned terri-

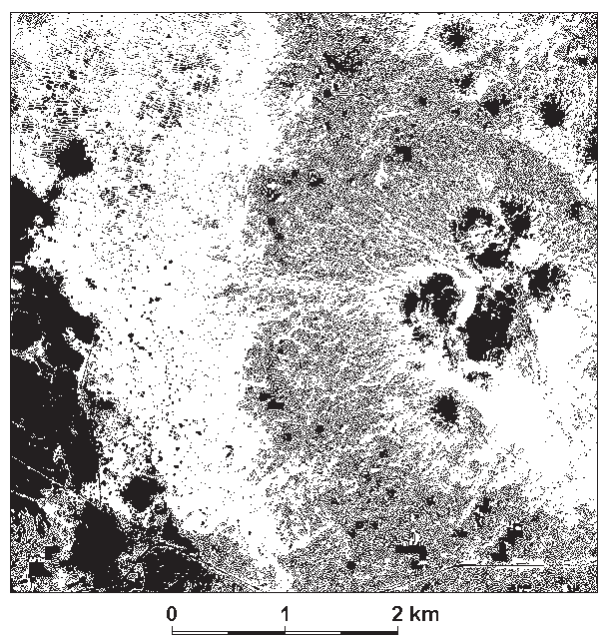

Fig. 3 - Pre-processed QuickBird satellite sub-scene for Bir el-Showish area tory belt is $16 \mathrm{~km}$ and the same territory can be surveyed every 3 days. An image extract $5 \times 5 \mathrm{~km}$ from the total satellite scene was applied for the landscape mapping in the Bir el-Showish area (Fig. 3). Some experience with the application of the QuickBird satellite imagery is already available (Bárta, Brůna 2006).

\section{Geodata processing procedures}

The object oriented approach was chosen as the method of semi-automatic image classification using e-Cognition procedures. The first step is the segmentation of the image into meaningful objects. The aim of the classification was to detect also small entities, e.g. individual bushes, so the scale parameter of the segmentation was very fine. The segmentation process was long lasting, but the fine scale parameter of the objects was necessary. After the segments were created, Normalized Difference Vegetation Index (NDVI) was used to differentiate vegetation and other surface. Supervised Nearest neighbor classification was then performed in both classes (vegetation and not-vegetation) 
separately. Six classes were created: rock outcrops, stabilized wind blown sand, fresh wind blown sand, green vegetation, cultivated fields and roads. Fields and roads were classified using membership functions, while the object shape criteria was length/width ratio. Fields had rectangular shape in the image and they were visually very well recognizable. They were fields with some crop (included into the vegetation class by NDVI) or just bare soil. Also objects which form roads had long and thin shape so they could be easily classified by the shape criteria. This is great advantage of the object oriented classification, because without the knowledge of other characteristics than radiometry it would be very difficult to classify (separate) those two classes. Their reflected values were the same as the ones of class soil.

The on-screen vectorizing was applied upon this computer data processing based output. The color classified image with coarse area margins respecting pixel edges was overlaid with much fine black-and-white panchromatic layer of original QuickBird with 50\% density. The combination of these both layers allowed the first the correct classification of the identified areas, and the second the right territorial delineation (outlining) classified areas. The procedure was also supported by ground data collected during the field works carried out by the authors on May 8-9, 2007. The map of the present landscape has been constructed dependently on the satellite image processing. The other maps, as explained below, were partially derived from this original map using supporting ground data and using deductive procedures based on terrain, geological, vegetation and other evidences (indices) of historical landscape development. The geodata processing run and maps were compiled in GIS SW ArcView GIS v. 3.2 .

\section{Landscape map compilation and application}

The first map completed using pre-processed satellite information was the map of the present landscape (Fig. 4). The process similar to traditional natural landscape map compilation used in Czechia was applied in the first stage of the Bir el-Showish present landscape map completing, because of the large part of the study territory (app. the eastern half) is mostly natural one composed of natural objects. The process is based on the integration of data on terrain, geology, humidity information, and other natural features as well as on land use. At the beginning of the map construction, the wadi network was extracted from the pre-processed satellite image. Such wadi network represents former drainage network similar to the same one serving as the landscape skeleton typical for more humid countries. The most wadis in the study area are clearly visible and semi-automatically identified because of their dendritic ground plan enhanced by fresh wind blown sand filling. The remaining "natural" territory was consequently filled by other natural landscape units starting from basalt mount tops, their hyperboloidic foothills called glacis covered with fresh wind blown sands, extended sloped dark sand plains covered by blackish gravel because the fine sand fraction was removed by the wind. The lowest part of the natural territory is covered by fresh light wind blown sands transformed in its central part into the long crescent-like app. 10-15 m high sand dune. The western part of the territory used mostly by humans is covered by palm groves and small field 
strips with and without agricultural crops. Such areas were enhanced using NDVI calculation. The discontinuous vegetation characterizes also the seasonally used, mostly bare areas close to more intensively used territory. The saline clay basin bottom (sebkha desert - probably the topographically lowest local territory) - the playa was distinguished as an extremely barren land.

The map of the present landscape of the Bir el-Showish area was subdued to the geographic analysis. It was focused on the hypothetical possibility to identify the ancient extend of the lake (wet land) basin at the beginning of the continuous settlement. The analysis reflected following facts:

a) subsistence of the uncultivated saline lowest section of the oasis with varying optical features

b) distribution of palm groves on heavy, not saline soils close to the basin bottom

c) dislocation of arable land on lighter loamy-sandy soils on the margins of basin bottom

d) position and movement of the recent large sandy dune eastwards from the cultivated and populated land of the basin bottom

e) shape, position and size of former wadies fulfilled with unstable sands on gentle slopes of mesas above the basin bottom

f) site of evident settlement from the Roman period in the area of Czech archeological concession

g) sites of recent villages in the oasis.

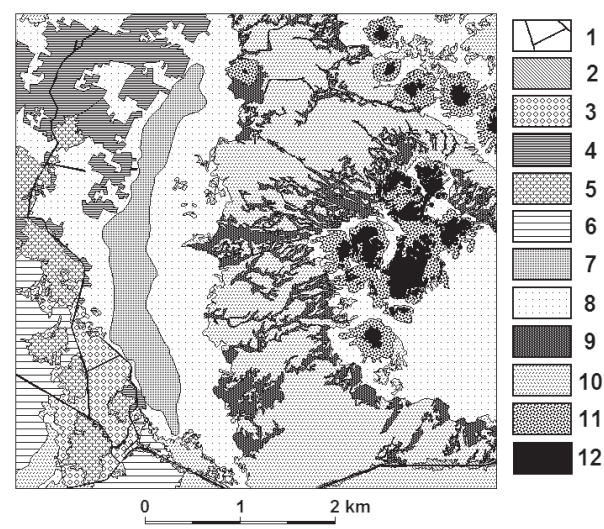

Fig. 4 - Map of present landscape of the Bir el-Showish area compiled using pre-processed satellite information and ground data. 1 - roads, 2 - recent road cutting, 3 - seasonally used land, 4 - arable land, 5 - palm groves, 6 - sebkha clay basin bottom, 7 - recent sand dune, 8 - unstable wind blown sand, 9 - wadi with fresh wind blown sand, 10 - stable (stone pawed) wind blown sand, 11 - table mount glacis, 12 - top volcanic layer of table mount.

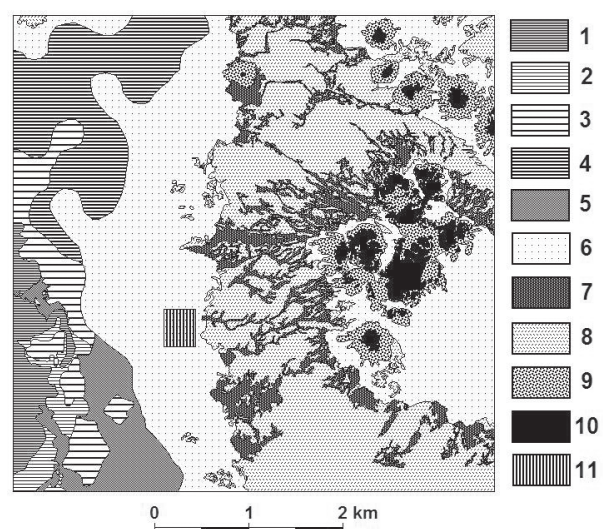

Fig. 5 - Estimated reconstruction of landscape at the beginning of permanent settlement of the Bir el-Showish area. 1 - saline clay basin bottom, 2 - less saline sandy basin bottom, 3 -less saline clay and sandy basin bottom , 4-loamy basin bottom, 5 - clay and loamy basin bottom, 6 - recent fresh wind blown sand cover, 7 - wadi with fresh wind blown sand, 8 - stable (gravel pawed) wind blown sand, 9 - table mount glacis, 10 - top volcanic layer of table mount, 11 - present Czech archaeological concession around the site of Roman period settlement). 

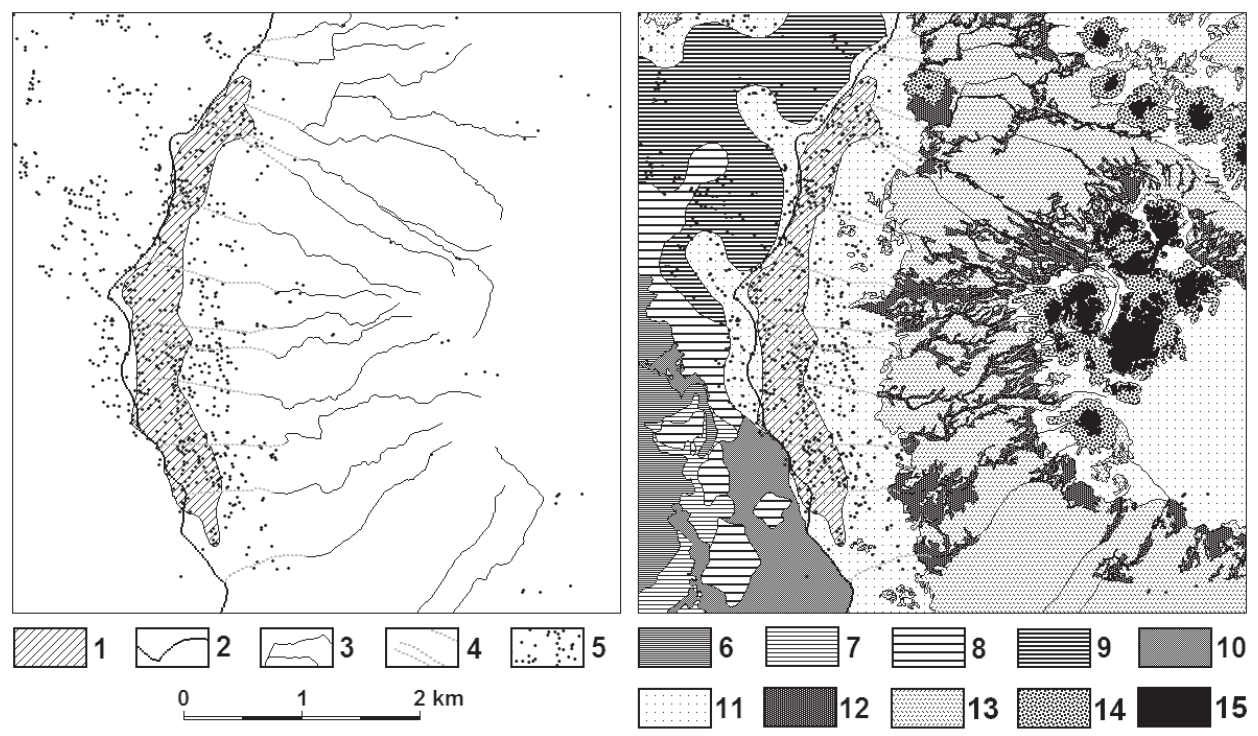

Fig. 6 - Territorial distribution of indices of ancient landscape structure (left) and their position in reconstructed natural landscape (right) of Bir e-Showish area. 1 - recent sand dune, 2 - estimated course of ancient coastline, 3 - ancient episodic water stream on wadi bottom, 4 - estimated water course on coastal plain, 5 - agwals with tamarisk shrubs, 6 saline clay basin bottom, 7 - less saline sandy basin bottom, 8 - less saline clay and sandy basin bottom, 9 - loamy basin bottom, 10 - clay and loamy basin bottom, 11 - fresh wind blown sand, 12 - wadi with fresh wind blown sand, 13 - stable (gravel pawed) wind blown sand, 14 - table mount glacis, 15 - top volcanic layer of table mount.

The areas "a", "b" and "c" were outlined using gentle curves as much as possible representing areas with homogenous ground features now visibly disturbed by products of human activities (Fig. 5).

Using by the satellite image and ground survey, additional information about other indices of ancient landscape was collected. The large crescent-like sand dune is constructed predominantly of the sand blown by the wind from coastal shallow water deposits. It is presumed that sand elements were deposited by the permanent and probably decisively by periodical water courses after rain storms. It means that the dune regardless its mobility follows partially in its shape the former lake coast and nearby shallow water sand banks. All the clay deposits originated in the deeper water according to that time bathygraphy. Because of the direction of prevailing winds at the time of the settlement beginning (NW as seen in present and ancient dune orientation in many sites in the neighborhood), the most sand mass was moved from the ancient lake coast to the SE. The ancient coastline is expected to be west from the dune in its northern part and partially covered by the sand in its southern part (Fig. 6). Some indices about the former irrigation network on the oasis basin bottom are provided by the reconstruction of the natural drainage network. The dendritic ground plan of wadis represents ancient water course network clearly regardless is not known how deep these wadies are because of sand filling. The width of wadies in between upper edges explains partially at least water volume flow- 


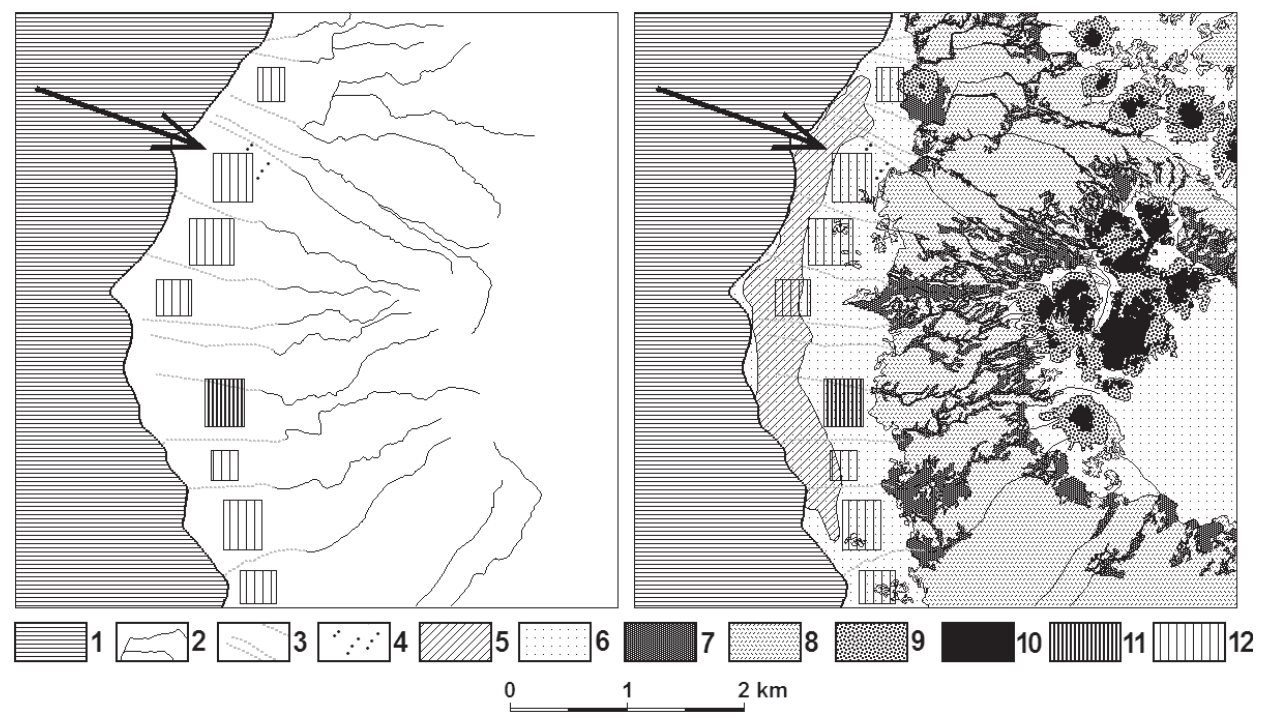

Fig. 7 - Estimated extend of former lake (wetland) and position of topic excavated archeological site compared with similar localities between water streams suitable for dwellings (left), the same situation incorporated into natural landscape (right). 1 - supposed lake water, 2 - ancient episodic water stream on wadi bottom, 3 - estimated course of ancient episodic water stream covered with recent wind blown sand, 4 - manawars, 5 - recent sand dune, 6 - unstable wind blown sand, 7 - wadi with fresh wind blown sand, 8 - stable (stone pawed) wind blown sand, 9 - table mount glacis, 10 - top volcanic layer of table mount), 11 - Czech archaeological concession present Czech archaeological concession around the site of Roman period settlement, 12 - possible settlement sites covered by sand, arrow shows the most perspective site for future archaeological excavations.

ing there downhill after rain storms and its erosion power. The extrapolation of watercourses into the area below wadies on the slopes is of course hypothetic because this part of territory is totally buried by wind blown sands. The territorial distribution of agwals microhills with tamarisk shrubs signalizes access to the ground water what can be accumulated in former river beds and deltas. These areas were better irrigated than the neighboring sites.

The final step of the of the natural landscape reconstruction consists of the estimation of the ancient water body (lake, wetland with coastal reed stands) position and the settlement situation on the fertile arable plain adjacent to the coastline. It was supposed, that areas subdued to the irrigation (in the Roman period) were located on slightly elevated plateaus between episodic water courses nearby the settlement protected from floods as well as from salinization coming from the lake through clay geological environment. Buildings and other constructions were located probably on the margin of barren land to save fertile land as commonly visible in present Saharan oases. The underground water supply canals - the "manawars" - were dug at least during the Roman period and the most of them served agricultural purposes, some of them provided drinking water for the local population. Because of the lack of fertile land and water resources, and regardless to well operating organization of population and its activities, it is not possible to imagine, that all suitable sites for 


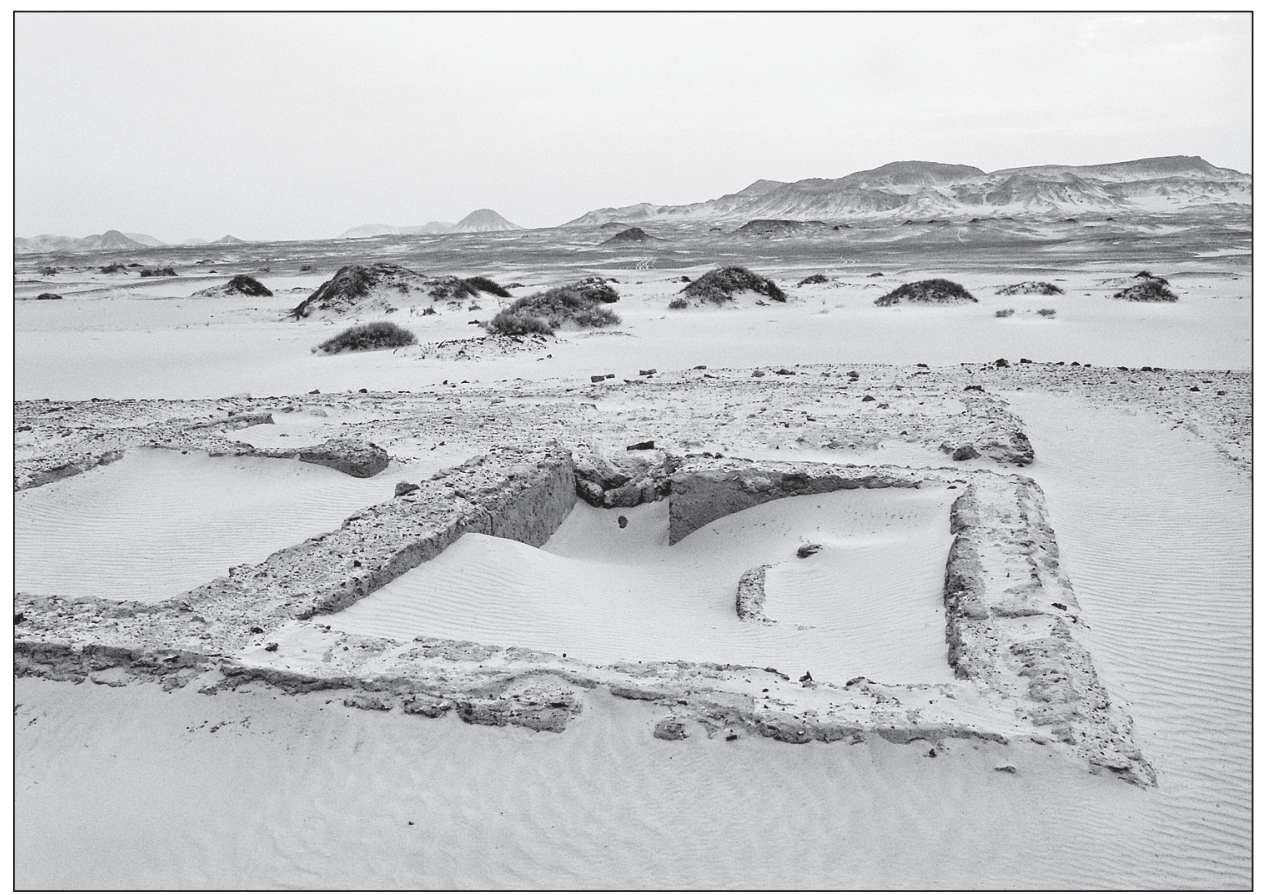

Fig. 8 - Typical landscape of Al-Bahríya oasis with table mounts, agwals microhills with tamarisk shrubs and recent Czech archaeological excavations

settlement in the neighborhood of fertile land were used for constructions. The shortest "safe distance" between settlements (app. max. 1/2 hour walking time to the site of agricultural field works and carry various tools - up to $2-3 \mathrm{~km}$ ) allowed to use the land for the dwelling location on some places only (Fig. 7). Only few such sites can be found in the study area and they are perspective from the archaeological view points.

\section{Discussion}

Using known facts and indices, the character of the lake (wet land) accumulation basin on the oasis bottom was estimated at the presumptive beginning of habitation. The used soil features allow define the original deep and shallow water areas with different deposition areas. It is presumed that the buildings were located (similarly to the present customs) on dry elevated sites outside the fertile agricultural land as well as the wet bottom of oasis basin and sparsely drained wadies. The most unstable wind blown sands on the oasis bottom are supposed coming from Neogene sandy weathering products and deposits outside the oasis. A small part of sands originated from lake coastal zone and beaches by the wind activity. The formation of the large sand dune stretched from $\mathrm{N}$ to $\mathrm{S}$ in the central part of the study area is probably linked with common presence and development of tamarix shrub groups on site where the ground water is accessible. Shrubs were able to curb the wind velocity, accu- 
mulate deposited sand and grove up on the tops of sandy microhills (agwals or nebkhas, Cílek 2007). This way, the bush roots were embedded close to aquifers regardless the bush green crown position on microhill tops (two springs are still active in this part of the oasis). Similar bush (Tamarix amplexicaulis, T. aphylla, T. nilotica) individuals live outside the dune but typically in the areas of moving sands only. Probably, the similar exposed sandy environment on the former coastal belt was preferred by shrubs in the time of open space colonization by plants. Since that time, shrubs accumulated the sandy hills and cover up to the 10-20 m high (thick). At the same time, the layer of the sand cover to the East from the dune is about $4 \mathrm{~m}$ deep only (as seen in archaeological excavations). These sands covered ancient network of wadies. Their ancient course to the lake or wetland on the oasis bottom is the subject of bargaining now only using the extrapolation of remaining sections of wadies coming down from sloped glacis on the foots of table mountains. It is supposed that the initial/original (Epipaleolithic) habitation at 7000-6000 BC (Svoboda 2005) also preferred similar sites as the excavated settlement did. There are some similar sites in the neighborhood here some of them are fully or partially covered by recent wind blown sands, one of them seems to be very perspective, because of fulfilling all hypothesis conditions for ancient settlement at the time, when the lake was in the neighborhood.

\section{Conclusion}

The Czech landscape mapping experience has disposing capacity arising from domestic long-term experience. The knowledge about the structure of the natural landscape where the drainage network and lake coastline course play the dominant role in the landscape pattern formation is applicable to a certain extent in the completely different desert environment where the water absence is deciduous at the present. The ancient local drainage network regardless it was used sporadically by the water offered certain localizing opportunities. Using certain facts, visions and indices, it is possible to identify sites serving in the deep past various purposes „petrified“ in some elements of the present landscape. Here is one step only how to look at the situation buried under the layer of deposits - archaeological shovel.

\section{References:}

ADELSBERGER, K. A., KIENIEWICZ, J, SMITH, J. R. (2008): Differentiating lacustrine from paludal environments in Dakhleh Oasis, Western Desert, Egypt. Geological Society of America Abstracts with Programs, 40, No. 6, 429 pp.

ADELSBERGER, K. A., SMITH, J. R. (2007): Sedimentology and geomorphology of a Pleistocene Wetland, Dakhleh Oasis, Western Desert, Egypt. Quaternary International, Supplement, 5-6, pp. 167-168.

ADELSBERGER, K. A., SMITH, J. R. (2009): Desert pavement development and landscape stability on the eastern Libyan Plateau, Egypt. Geomorphology, No. 107, pp. 178-194.

BÁRTA, M., BRU゚NA, V. (2006): Pyramidy a vodovody v poušti. Vesmír, 169, No. 2, pp. 80-85.

BÁRTA, M. (2005): Průzkum oázy el-Hajez, oáza Baharíja. http://egyptologie.ff.cuni.cz/? req=doc:baharija\&lang=cs. 


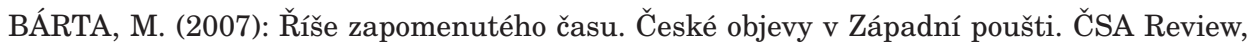
No. 3-4, pp. 20-28.

BÁRTA, M., BRŮNA, V., ČERNÝ, V., MUSIL, J., SVOBODA, J. A., VERNER, M. (2004): Report on the survey and trial excavations of the Czech Institute of Egyptology, carried in the area of El-Hayez, Baharia Oasis (2nd season, 6.3.-31.3.2004). Přehled výzkumů, 45, Archeologický ústav, Brno, pp. 23-28.

BRU゚NA, V. (2006): Mapování oázy el-Hajéz. http://bruna.geolab.cz/files/egypt/acta_oecologica-elhajez.pdf.

CASTEL, G., TALLET, P. (2001): Les inscriptions d'El-Harra, oasis de Bahariya. BIFAO, 101, pp. 99-136.

CÍLEK, V. (2007): Nejméně známá část naší planety. Vesmír, 170, No. 10, pp. 626-627.

CREMASCHI, M., DI LERNIA, S. (1999) Holocene Climatic Changes and Cultural Dynamics in the Libyan Sahara. African Archaeological Review, No. 16, pp. 211-238.

DEMEK, J, QUITT, E., RAUŠER, J. (1975): Fyzickogeografické regiony ČSR. Map in the scale of 1:500,000. Geografický ústav ČSAV, Brno.

FAIRBAIRN, A., O'CONNOR, S., MARWICK, B., eds. (2009): New Directions in Archaeological Science. Terra Australis 28. ANU E Press, Canberra, 262 pp.

GOJDA, M. (2000): Archeologie krajiny. Academia, Praha, 238 pp.

GOJDA, M. (2004): Letecká archeologie a dálkový průzkum. In: Kuna, M., et al.: Nedestruktivní archeologie. Teorie, metody a cíle, Academia, Praha, pp. 49-116.

IVAN, A. et al. (1987): Přírodní prostředí. Map in the scale of 1:750,000. In: Atlas obyvatelstva ČSSR. Díl V. Životní prostředí, rekreace. GGÚ ČSAV/FSÚ, Brno, Praha.

KOBUSIEWICZ, M., KABACINSSKI, J., SCHILD, R., IRISH, J. D., WENDORF, F. (2004): Discovery of the first Neolithic cemetery in Egypt's western Desert. Antiquity, No. 78, pp. 566-578.

KOLEJKA, J. (1992): Typy přírodní krajiny ČSFR. Map in the scale of $1: 1,000,000$. In: Atlas životního prostředí a zdraví obyvatelstva ČSFR. GGÚ ČSAV/FV ŽP, Brno, Praha.

KOLEJKA, J. (1999): Krajinné mapy a jejich klasifikace. Geodetický a kartografický obzor, 45/87, No. 12, pp. 273-278.

KOLEJKA, J. (2006): Atlas krajiny České republiky vstupuje do druhé poloviny př́ípravného období. Geoinformace, No. 1, pp. 42-44.

KOLEJKA, J., LIPSKÝ, Z. (1999): Mapy současné krajiny. Geografie, 104, No. 3, pp. 161-175.

KOLEJKA, J., LIPSKY, Z. (2007): Landscape maps in the Czech Republic in connection with world and European development. Ekologie krajiny. Journal of landscape Ecology, pp. 54-74.

KORČÁK, J. (1936): Regionální typ v pojetí statistickém. In: Sborník III. sjezdu československých geografů v Plzni 1935, Ceskoslovenská grafická unie a. s., Praha, pp. 111-112.

KRÁL, J. (1930): Úvahy o rozdělení československých Karpat na přírodní oblasti a pojmenování těchto oblastí. Sborník filosofické fakulty University Komenského, 7, No. 54 (1), pp. 1-33.

MOSCHELESOVÁ, J. (1936): Zeměpisné oblasti - krajiny - v pojetí regionálního zeměpisu. In: Sborník III. sjezdu československých geografư v Plzni 1935, Československá grafická unie a. s., Praha, pp. 107-108.

PARCAK, S. (2009): Satellite Remote Sensing for Archaeology. Routledge, 320 pp.

RASHEED, M. A., GAD, A., ZÖLITZ-MÖLLER, R., DARWISH, K. M. (2008): Geographic Mapping and Analysis Using GIS of Study Areas in Bahariya Oasis, Egypt. AmericanEurasian Journal of Agriculture and Environmental Science, 4, No. 1, pp. 125-130.

SERENO, P. C., GARCEA, E. A. A., JOUSSE, H., STOJANOWSKI, C. M., SALIĖGE, J.-F., et al. (2008): Lakeside Cemeteries in the Sahara: 5000 Years of Holocene Population and Environmental Change. PLoS ONE, 3, No. 8, e2995. doi:10.1371/journal.pone.0002995.

STIEBING, W. H. (1989): Out of the Desert? Archaeology and the Exodus/Conquest Narratives. Prometheus Books, Amherst, NY, 189 pp.

SVOBODA, J. A. (2005): Egypt před faraóny. Vesmír, 135, No. 2, pp. 79-84.

SVOBODA, J. A. (2006): Prehistory of the southern Bahariya Oasis, Western Desert, Egypt. An outline. Archaeology, Ethnology and Anthropology of Eurasia, 28, No. 4, pp. 18-30. 


\section{VYUŽITÍ ZKUŠENOSTÍ Z ČESKÉHO KRAJINÁŘSKÉHO VÝZKUMU V POUŠTNÍM PROSTŘEDÍ NA POMOC ARCHEOLOGICKÉMU STUDIU}

Česká geografie disponuje více než stoletou tradicí krajinářského výzkumu. Řada poznatků ze studia krajiny u nás a z tvorby krajinných map je využitelná také v jiném geografickém prostředí. Krajinné mapy znázorňují krajinu jako harmonický komplex všech složek. Ze znalosti vzájemných vztahů mezi složkami lze odvodit řadu praktických poznatků. Pro potřeby podpory archeologického výzkumu českých odborníků v egyptské oáze Baharíja byla provedena krajinářská studie využívající jak technologie dálkového průzkumu Země a geografických informačních systémů, tak řady možností účelové interpretace map současné a přírodní krajiny zájmového území, pořízených výše uvedenými nástroji. Př́ístrojovou interpretací multispektrálního družicového snímku vysokého rozlišení QuickBird byly zjištěny základní kategorie povrchu zájmového území Bir el-Šoviš $(5 \times 5 \mathrm{~km})$ a ty pak upřesněny a diferencovány během vektorizace na obrazovce. Výsledkem byla mapa současné krajiny části oázy Baharíja. Východní polovina listu představuje více-méně přírodní krajinu, západní polovina je silně zemědělsky kultivovaná. Za pomoci geologické mapy a terénního průzkumu byla také v západní polovině území identifikována př́írodní struktura krajiny zohledněním typů půd, terénu, dávné drenážní sítě a geologického substrátu. Účelovou interpretací takto konstruované typologické mapy přírodní krajiny byl odhadnut průběh břehové čáry původního jezera (mokřadu), které zde existovalo doloženě 8-7 tis. let před současností a snad až do římské doby. Podobně byla rekonstruována drenážní sít tehdejší doby. Na základě využití indicií, reprezentovaných sítí vádí, rekonstruovaných úseků koryt, výskytu hluboce kořenících keřu tamaryšků a odhadnutého pohybu písečné duny vyváté z prríbřežních a plážových písků jezera a zjištěné a aktuálně zkoumané sídelní lokality byla identifikována řada lokalit splňujících kritéria vhodného osídlení v době existence jezera (mokřadu). Zohledněním hospodářských a sociálních možností území se jako vhodná pro výkopy jeví jediná další perspektivní lokalita. Na ní lze soustředit pozornost dalšího výzkumu.

Obr. 1 - Poloha oázy Baharíja

Obr. 2 - Poloha studovaného území v oáze Baharíja

Obr. 3 - „Předzpracovaná“ subscéna družice QuickBird pro území osady Bir el-Šoviš

Obr. 4 - Mapa současné krajiny okolí osady Bir el-Šoviš sestavená za využití předzpracovaného družicového snímku a údajů pozemního výzkumu. 1 - cesty, 2 - mladé silniční zářezy, 3 - občasné využívané území, 4 - orná půda, 5 - palmové háje, 6 -jílovitá sebcha na dne pánve (plaje), 7 - aktivní písečná duna, 8 - nestabilizované svěží váté písky, 9 - vádí vyplněná čerstvým vátým pískem, 10 - stabilizované (oblázkovou dlažbou) váté písky, 11 - glacis na úpatí stolových hor, 12 - lávové vrstvy vrcholových plošin stolových hor.

Obr. 5 - Přribližná rekonstrukce krajiny na počátku trvalého osídlení v okolí osady Bir el-Šoviš. 1 - silně zasolené a zajílené dno pánve (plaje), 2 - mírně zasolené a zajílené dno pánve (plaje), 3 - mírně zasolené zasolené jílovito-písčité dno pánve (plaje), 4 - zahliněné dno pánve (plaje), 5 -jílovito-hlinité dno pánve (plaje), 6 - nestabilizované svěží váté písky, 7 - vádí vyplněná čerstvým vátým pískem, 8 - stabilizované (oblázkovou dlažbou) váté písky, 9 - glacis na úpatí stolových hor, 10 - lávové vrstvy vrcholových plošin stolových hor, 11 - prostor české archeologické koncese v místě sídliště z doby římské.

Obr. 6 -Rozmístění indicií dávné krajinné struktury (vlevo) a jejich poloha v rekonstruované přírodní krajině (vpravo) v okolí osady Bir el-Šoviš. 1 - aktivní písečná duna, 2 - odhad průběhu dávné pobřežní čáry, 3 - dávné občasné vodní toky na dnech vádí, 4 - odhad trasy odtoku na pobřežní rovině, 5 - pahorky agwals keři tamaryšků, 6 - silně zasolené a zajílené dno pánve (plaje), 7 - mírně zasolené a zajílené dno pánve (plaje), 8 - mírně zasolené zasolené jílovito-písčité dno pánve (plaje), 9 - zahliněné dno pánve (plaje), 10 - jílovito-hlinité dno pánve (plaje), 11 - nestabilizované svěží váté písky, 12 - vádí vyplněná čerstvým vátým pískem, 13 - stabilizo- 
vané (oblázkovou dlažbou) váté písky, 14 - glacis na úpatí stolových hor, 15 - lávové vrstvy vrcholových plošin stolových hor.

Obr. 7 - Odhad rozsahu bývalého jezera (mokřadu) a poloha aktuálního zkoumaného archeologického okrsku k porovnání s podobnými lokalitami mezi řečišti vhodnými k obývání (vlevo), tatáž situace vložená do přírodní krajiny (vpravo). 1 - předpokládané jezerní vody, 2 - dávné občasné vodní toky na dnech vádí, 3 - odhad průběhu epizodických toků v území překrytém recentními vátými písky, 4 - otvory podzemních kanálů manawars, 5 - aktivní písečná duna, 6 - nestabilizované svěží váté písky, 7 - vádí vyplněná čerstvým vátým pískem, 8 - stabilizované (oblázkovou dlažbou) váté písky, 9 - glacis na úpatí stolových hor, 10 - lávové vrstvy vrcholových plošin stolových hor, 11 - prostor české archeologické koncese v místě sídliště z doby římské, 12 -možné lokality sídlišt' zakryté pískem, šipka ukazuje nejperspektivnější místo pro archeologické vykopávky.

Obr. 8 - Typická krajina oázy Bahríja se stolovými horami, mikropahorky agwals s keři tamaryšků a současné české archeologické vykopávky.

J. Kolejka is affiliated with the Institute of Geonics, Academy of Sciences of Czech Republic, Brno Branch, Drobného 28, 60200 Brno, Czechia, e-mail: kolejka@geonika.cz. L. Misáková is affiliated with Mendel University of Agriculture and Forestry, Faculty of Forestry and Wood Technology, Institute of Geoinformation Technologies, Zemědělská 3, 61300 Brno, Czechia, e-mail: xmisako0@node.mendelu.cz.V. Bruna is affiliated with Jan Evangelista Purkyně University, Faculty of Environment, Laboratory of Geoinformatics, Dělnická 21, 43401 Most, Czechia, e-mail: bruna@geolab.cz.

Initial submission 11 November 2009; final acceptance 3 May 2010.

\section{Citační vzor:}

KOLEJKA, J., MISÁKOVÁ, L., BRŮNA, V. (2010): Application of the Czech mandscape research experience in the desert environment to support archeological study. Geografie, 115, č. 3 , s. 347-360. 